\title{
Metabolic Abnormalities and Metabolic Syndrome among Cameroonian Women: Comparative Study between Pre- and Post-Menopausal Women
}

\author{
Françoise Raïssa Ntentie 1,2*, Mary-Ann Angie Mbong2, Maxwell Wandji Nguedjo ${ }^{2,3}$, \\ Boris Rornald Tonou Tchuenté2,3, Ousmane Mfopou Mboindi ${ }^{2}$, Boris Gabin Kingue Azantsa ${ }^{2}$, \\ Judith Laure Ngondi2, Julius Enyong Oben²
}

\begin{abstract}
${ }^{1}$ Department of Earth and Life Sciences, Higher Teachers' Training College, University of Maroua, Maroua, Cameroon ${ }^{2}$ Laboratory of Nutrition and Nutritional Biochemistry, Department of Biochemistry, University of Yaounde 1, Yaounde, Cameroon ${ }^{3}$ Centre for Food and Nutrition Research, Institute of Medical Research and Medicinal Plants Study, Ministry of Scientific Research and Innovation, Yaounde, Cameroon

Email: *franc_ntentie@yahoo.fr
\end{abstract}

How to cite this paper: Ntentie, F.R., Mbong, M.-A.A., Nguedjo, M.W., Tchuenté, B.R.T., Mboindi, O.M., Azantsa, B.G.K., Ngondi, J.L. and Oben, J.E. (2020) Metabolic Abnormalities and Metabolic Syndrome among Cameroonian Women: Comparative Study between Pre- and PostMenopausal Women. Journal of Biosciences and Medicines, 8, 76-89.

https://doi.org/10.4236/jbm.2020.87008

Received: April 20, 2020

Accepted: July 25, 2020

Published: July 28, 2020

Copyright $\odot 2020$ by author(s) and Scientific Research Publishing Inc. This work is licensed under the Creative Commons Attribution International License (CC BY 4.0).

http://creativecommons.org/licenses/by/4.0/ (c) $\underset{\mathrm{By}}{\text { i }}$ Open Access

\begin{abstract}
The high prevalence of non-communicable diseases is a challenging problem in the Cameroonian population and women are the most affected. The aim of the present study was to determine and compare the prevalence of metabolic abnormalities and metabolic syndrome (MetS) among pre- and post-menopausal women living in urban areas in Cameroon. A total of 499 women were recruited during a mass health campaign in 2018. Metabolic abnormalities were diagnosed using International Diabetes Federation (IDF) criteria. MetS was defined using IDF criteria with slight modification (total cholesterol used instead of HDL cholesterol). Logistic regression was used to estimate the association between menopausal status and metabolic abnormalities and MetS in age control and non-control models. The prevalence of high waistto-hip ratio $(56.8 \%$ vs $36.3 \%, \mathrm{p}<0.001)$, elevated fasting blood glucose (glycemia $\geq 100 \mathrm{mg} / \mathrm{dL})(38.7 \%$ vs $26.9 \%, \mathrm{p}=0.006)$; diabetes $(14.6 \%$ vs $5.7 \%, \mathrm{p}=$ $0.001)$; high triglycerides level $(29.7 \%$ vs $17.1 \%, \mathrm{p}=0.002)$; hyperlipidemia (high total cholesterol and or triglycerides levels) $(45.0 \%$ vs $30.8 \%, \mathrm{p}=0.002)$; and elevated blood pressure $(67.9 \%$ vs $56.1 \%, \mathrm{p}=0.007)$ were higher among post-menopausal than pre-menopausal women. The overall prevalence of MetS was $30.1 \%$ and post-menopausal women were more affected $(33.8 \%$ vs 25.0\%; $\mathrm{p}=0.034$ ). The odds ratio of MetS was 1.888 (95\% CI: 1.016 - 3.507) when age was covariate, but was slightly reduced without age control $(\mathrm{OR}=$ 1.532; 95\% CI: 1.031 - 2.275). Metabolic abnormalities seem to be a major
\end{abstract}


health problem among Cameroonian women and menopausal status increased the risk of developing a cardiovascular event.

\section{Keywords}

Metabolic Abnormalities, MetS, Menopausal Status, Cameroonian Women

\section{Introduction}

Metabolic syndrome (MetS) is a constellation of factors that promote the development of cardiovascular diseases (CVD), diabetes mellitus type 2 and all-cause mortality [1] [2]. The prevalence of MetS is increasing worldwide and African populations are not spared with female populations more affected as compared to males [3] [4] [5]. This prevalence of the MetS increases with menopause and may partially explain the apparent increase in CVD after menopause [6]. Previous studies have shown that MetS and CVD are more common in women above 55 years of age with significant increase in individual risk factors in the post-menopausal phase [7] [8]. However, controversy exists about whether menopause increases the risk of CVD independent of normal aging. Some studies have demonstrated increased risk of CVD after menopause and others have not [9] [10] [11]. Menopause with its incidental hormonal changes appears to increase the risk of CVD independently of normal aging. Also, premenopausal women may be protected against CVD compared to men and postmenopausal women of a similar age group suggesting that estrogen deficiency causes a rapid acceleration in CVD risk [12]. Moreover, many of the features of the MetS (central obesity and dyslipidemia with elevated TG, reduced HDL, and small dense LDL particles) emerge with estrogen deficiency in postmenopausal women, which may explain the acceleration of CVD in women after menopause [6]. It has been reported that menopause is closely related to insulin resistance and cardiovascular risk factors [13]. But the influence of menopause on blood pressure (BP) is difficult to evaluate because menopause coincides with aging. Some studies have reported a strong association between BP and menopause, but others not [10] [11]. However, the emergence of metabolic risk factors in post-menopausal phase may be a direct result of ovarian failure with estrogen deficiency. Decrease in estrogen production is thought to be responsible for a substantial proportion of increased cardio-metabolic risk factors in post-menopausal women [14]. Changing hormonal milieu with decreasing estrogen and alteration of its ratio to testosterone has been implicated as a causal factor for the emergence of MetS at menopausal transition [15] [16]. In fact, menopausal status is accompanied by unfavorable levels of cardiovascular risk factors, like changes in body fat, distribution from gynoid to android pattern, abnormal plasma lipids, increased sympathetic tone, endothelial dysfunction, vascular inflammation and increased blood pressure [17]. The causal effect of menopause on MetS is still unclear even 
if few studies have investigated the effect of menopause on the development of the MetS independently of age [14] [16] [18] [19] [20]. To our knowledge, there are few studies [21] on the effect of menopause on the development of MetS and data on an association between the MetS and menopausal status among Cameroonian women are very scarce or inexistent. The reason why the present study has been initiated aiming at evaluating and comparing the prevalence of MetS and its individual components among a set of pre and post-menopausal women living in urbanized areas.

\section{Methodology}

\subsection{Description of Population and Area of Study}

During nutritional surveys organized by the Cameroon Nutritional Society in 2018 in some urbanized cities of Cameroon (Nkongsamba, Foumban, Maroua, Dschang), Cameroonian women aged 35 years and above were randomly recruited and categorized according to their hormonal status obtained using questionnaire. Women were defined as post-menopausal if they had reported their last menses to be at least 12 months prior to the survey meanwhile pre-menopausal were defined as such if they had an unchanged and regular menstrual pattern during the last five years, without typical climacteric complaints [22]. Pregnant, lactating, under contraceptive or hormone replacement therapy (HRT) women, as well as those who had undergone menopause due to hysterectomy or cessation of periods other than by a natural cause were excluded from the study. Those under any treatment against metabolic diseases were also excluded.

\subsection{Sample Size Determination}

At the end of the nutritional survey, 642 women were recruited, 30 were pregnant, 37 were lactating, 71 were under contraceptive, 05 had undergone a hysterectomy. A total of 499 apparently healthy women regrouped as pre-menopausal $(\mathrm{n}=212,35-48$ years $)$ and post-menopausal $(\mathrm{n}=287 ; 42-70$ years $)$ were eligible and included to the study.

\subsection{Questionnaire}

A questionnaire inspired from "WHO steps instrument for chronic diseases" relative to age, menopausal status, main income, lifestyle habits (cigarette, alcohol, level of physical activities, fruits and vegetable consumption), parental and personal medical history of CVD, use of any medication was conceived and a pre-test was realized to test their validity and reliability prior to the survey. Under the assistance of well-trained and qualified interviewers, each woman was subjected to a face-to-face interview using the validated questionnaire.

\subsection{Anthropometric Measurements}

Weight was recorded to the nearest $0.1 \mathrm{~kg}$ using an electronic balance (Tanita ${ }^{\mathrm{mm}}$ BC-418 Segmental Body Composition Analyzer/Scale) to light clothing women. 
Height was measured with a Harpended ${ }^{\mathrm{mm}}$ stadiometer to the nearest $0.1 \mathrm{~cm}$. Waist circumference was taken at the mid-point between the bottom rib and the hip bone without restrictive garments and hip circumference was measured as the maximum circumference at the level of the buttocks. All measurements were recorded to the nearest $\mathrm{cm}$ using a flexible non-expandable tape measure. Waist-to-hip ratio (WHR) was computed as well as Body mass index (BMI) using the formula: $\mathrm{BMI}=$ Weight $(\mathrm{kg}) / \mathrm{Height}^{2}(\mathrm{~m})$ and expressed in $\mathrm{kg} / \mathrm{m}^{2}$.

\subsection{Arterial Blood Pressure Measurements}

Three measurements of BP were taken with an Automatic Blood Pressure Monitor with Heart Sense ${ }^{\circledR}$ (Samsung) in a sitting position. The first measurement was taken after a 10 minutes rest in a sitting position and was followed by two subsequent measurements in the middle and at the end of the interview. The average of the three measurements was used to assess the presence or absence of elevated blood pressure.

\subsection{Blood Sampling}

After a 12-hours overnight fast, about $4 \mathrm{ml}$ of venous blood was collected in EDTA tubes by venipuncture in the hand of each woman. The plasma was obtained by centrifugation of the collected sample and aliquots were frozen at $-20^{\circ} \mathrm{C}$ for further biochemical analyses.

\subsection{Biochemical Analyses}

Fasting blood glucose was the first parameter to be measured at the beginning of the activities of the survey by the Glucose Oxidase-Peroxydase (GOP-POD) method [23] using a glucometer (GlucoPlusTM) and glucose test strips (GlucoPlusMD). Total cholesterol [24] and triglycerides [25] levels were performed by standard enzymatic spectrophotometric methods using ChronoLab Diagnostic Kits in the laboratory.

\subsection{Ethical Considerations}

The Helsinki declaration on medical ethics was respected. Approvals were obtained from the National Ethics Committee and all the participants gave their consent prior to enrolment to the survey.

\subsection{Diagnosis of Metabolic Abnormities and MetS}

Nutritional status was evaluated using WHO criteria as follows: overweight was defined as a BMI between $25-29.9 \mathrm{~kg} / \mathrm{m}^{2}$ and obesity as a BMI $\geq 30 \mathrm{~kg} / \mathrm{m}^{2}$ [26]. Abdominal obesity was diagnosed with a waist circumference $\geq 80 \mathrm{~cm}$ [27]. Concerning glucose metabolic abnormalities, prediabetes and diabetes were diagnosed with a fasting blood glucose level between $110-125 \mathrm{mg} / \mathrm{dL}$ and $\geq 126$ $\mathrm{mg} / \mathrm{dL}$ respectively according to WHO definition [28]. Women with Systolic BP $\geq 130 \mathrm{mmHg}$ and or Diastolic $\mathrm{BP} \geq 85 \mathrm{mmHg}$ were considered as having ele- 
vated BP according to NCEP ATP III criteria [29]. Meanwhile, those with Systolic BP $\geq 140 \mathrm{mmHg}$ and or Diastolic BP $\geq 90 \mathrm{mmHg}$ were classified as hypertensive [30]. For lipid disturbances, women with total cholesterol level $\geq 200$ $\mathrm{mg} / \mathrm{dL}$ and or triglycerides level $\geq 150 \mathrm{mg} / \mathrm{dL}$ were considered hyperlipidemic [29]. The MetS was diagnosed using IDF criteria [27] which has been shown to be the more appropriate for the Cameroonian population [31]. This IDF definition is based on waist circumference $\geq 80 \mathrm{~cm}$ and two or more of any of the following: fasting triglycerides level $\geq 1.5 \mathrm{mg} / \mathrm{dL}$; fasting HDL cholesterol $<50 \mathrm{mg} / \mathrm{dL}$; SBP $\geq 130 \mathrm{mmHg}$ and/or DBP $\geq 85 \mathrm{mmHg}$; fasting blood glucose level $\geq 100 \mathrm{mg} / \mathrm{dL}$. Since total cholesterol has been shown to be directly related to mortality from coronary heart diseases even in populations with low cholesterol concentrations, we used total cholesterol ( $\geq 200 \mathrm{mg} / \mathrm{dL}$ ) instead of HDL-C as previously reported in other studies [32] [33].

\subsection{Data Analyses}

Data were entered in Excel spread sheet and double checked for errors. Statistical analyses were done using Statistical Package for Social Sciences (SPSS) 20.0 for Windows. Descriptive analysis results were presented as mean values \pm standard deviations for continuous variables or as percentage for categorical variables. Student $\mathrm{t}$-test was performed to compare continuous variables while Chi-square test was used to compare categorical variables between pre and post-menopausal women. Logistic regressions were performed to evaluate the risk of developing metabolic abnormalities and MetS. Two types of models were used: the first model was the crude model without any adjustment and the second model was adjusted for age (age as covariate). Moreover, pre-menopausal women were taken as reference group. For $\mathrm{p}$-values $\leq 0.05$ results were considered as statistically significant.

\section{Results}

\subsection{Description of the Study Population}

The general description of the study population presented in Table 1 shows that among the 499 women recruited, 211 (42.5\%) were pre-menopausal and 287 (57.5\%) were post-menopausal. According to marital status, $72.2 \%$ were in a relationship while $27.8 \%$ were not living in couple. A proportion of $6.6 \%$ of participants were smokers. For alcohol consumption, 32.9\% were abstainers, 59.3\% were moderate and $7.8 \%$ were heavy alcohol consumers. The family history of a CVD was positive in $30.5 \%$ of participants. As concerns eating habits, $48.3 \%$ and $63.1 \%$ of participants were low vegetable and fruit consumers respectively with no statistical difference between pre and post-menopausal women with the Chisquare test. Participants were classified into two groups according to their level of physical activities and $34.1 \%$ of them had low level of physical activities versus $65.9 \%$ with moderate level of physical activities. Regarding sources of income, it was noted that $59.4 \%$ of women had their income from assistance, $11 \%$ had a 
Table 1. General Characteristic of the study population.

\begin{tabular}{|c|c|c|c|c|c|}
\hline & & $\begin{array}{c}\text { Overall } \\
n=499(\%)\end{array}$ & $\begin{array}{l}\text { Pre-menopausal } \\
\mathrm{n}=212(42.5 \%)\end{array}$ & $\begin{array}{l}\text { Post-menopausal } \\
\mathrm{n}=287(57.5 \%)\end{array}$ & $P$-value \\
\hline \multirow{3}{*}{ Marital status } & Single & $32(6.4)$ & $18(8.5)$ & $14(4.9)$ & \multirow{3}{*}{$<0.001$} \\
\hline & Maried & $360(72.2)$ & $186(82.0)$ & $186(64.8)$ & \\
\hline & Widowed/divorced & $107(21.4)$ & $87(9.5)$ & $87(30.3)$ & \\
\hline \multirow{3}{*}{$\begin{array}{l}\text { Source of } \\
\text { income }\end{array}$} & Assistance & $296(59.4)$ & $140(66.2)$ & $156(54.3)$ & \\
\hline & Permanent & $55(11.0)$ & $27(12.9)$ & $28(9.9)$ & \multirow[t]{2}{*}{0.018} \\
\hline & Temporary & $148(29.6)$ & $45(20.9)$ & $103(35.8)$ & \\
\hline \multirow[t]{2}{*}{ Tobacco use } & Yes & $6.6(33)$ & $3.8(8)$ & $8.7(25)$ & \multirow[t]{2}{*}{0.081} \\
\hline & Abstainers & $164(32.9)$ & $60(28.1)$ & $104(32.2)$ & \\
\hline \multirow[t]{2}{*}{$\begin{array}{c}\text { Alcohol } \\
\text { consumption }\end{array}$} & Moderate & $296(59.3)$ & $134(63.4)$ & $165(56.5)$ & \multirow[t]{2}{*}{0.108} \\
\hline & High & $39(7.8)$ & $18(8.5)$ & $21(7.3)$ & \\
\hline \multirow{3}{*}{$\begin{array}{l}\text { Family history } \\
\text { of }\end{array}$} & HTN & $104(20.9)$ & $48(22.9)$ & $56(19.7)$ & 0.429 \\
\hline & Diabetes & $74(14.8)$ & $31(14.6)$ & $43(15.0)$ & 0.950 \\
\hline & CVD & $152(30.5)$ & $70(33.0)$ & $82(28.5)$ & 0.330 \\
\hline Fruits & Low & $315(63.1)$ & $122(57.7)$ & $193(67.2)$ & \multirow{2}{*}{0.1210 . } \\
\hline consumption & Regular & $184(36.9)$ & $90(42.3)$ & $94(32.8)$ & \\
\hline \multirow{2}{*}{$\begin{array}{c}\text { Vegetable } \\
\text { consumption }\end{array}$} & Low & $241(48.3)$ & $118(55.5)$ & $123(42.8)$ & \multirow{2}{*}{0.286} \\
\hline & Regular & $258(51.7)$ & $94(44.5)$ & $164(57.2)$ & \\
\hline \multirow{2}{*}{$\begin{array}{l}\text { Level of physical } \\
\quad \text { activities }\end{array}$} & Low & $170(34.1)$ & $84(39.7)$ & $86(29.9)$ & \multirow{2}{*}{0.069} \\
\hline & Moderate & $329(65.9)$ & $128(60.3)$ & $201(70.1)$ & \\
\hline
\end{tabular}

permanent income while $29.6 \%$ had a temporary salary with a significant difference between pre and post-menopausal women (Table 1).

\subsection{Anthropometric, Clinical and Biochemical Characteristics of the Study Population}

Table 2 presents anthropometric, biochemical and hemodynamic characteristics of the study population stratified by menopausal status. The mean age (56.06 \pm 6.90 years), SBP $(139.17 \pm 25.07 \mathrm{mmHg}), \mathrm{DBP}(87.23 \pm 16.42 \mathrm{mmHg})$, WHR $(0.86 \pm 0.11)$, glucose level $(106.54 \pm 39.22 \mathrm{mg} / \mathrm{dL})$ and triglycerides level $(114.55$ $\pm 66.42 \mathrm{mg} / \mathrm{dL})$ were significantly higher among post-menopausal women meanwhile heart rate $(80.07 \pm 13.28$ pulse/min $)$ and hip circumference $(107.89 \pm$ $13.32 \mathrm{~cm}$ ) were significantly higher in the pre-menopausal group.

\subsection{Prevalence of Metabolic Abnormalities and Metabolic Syndrome According to Menopausal Status}

Concerning metabolic abnormalities, results presented in Table 3 showed that post-menopausal women were the most affected by impaired glucose level (glycemia $\geq 100 \mathrm{mg} / \mathrm{dL}$ ) (38.7\%), diabetes (14.6\%), hyperlipidemia (45.0\%), high 
Table 2. Anthropometric, biochemical and hemodynamic characteristic of the study population.

\begin{tabular}{ccccc}
\hline & Overall & Pre-menopausal & Post-menopausal & P-value \\
\hline Age (years) & $49.87 \pm 9.21$ & $41.50 \pm 3.64$ & $56.06 \pm 6.90$ & 0.0001 \\
BMI (kg/m²) & $28.04 \pm 6.53$ & $28.20 \pm 6.67$ & $27.92 \pm 6.44$ & 0.631 \\
SBP (mmHg) & $134.14 \pm 24.38$ & $127.34 \pm 21.69$ & $139.17 \pm 25.07$ & 0.0001 \\
DBP (mmHg) & $85.57 \pm 16.57$ & $83.33 \pm 16.55$ & $87.23 \pm 16.42$ & 0.009 \\
Pulse (pulse/min) & $77.33 \pm 13.82$ & $80.07 \pm 13.28$ & $75.75 \pm 13.91$ & 0.002 \\
Waist (cm) & $89.78 \pm 15.06$ & $89.76 \pm 13.03$ & $89.79 \pm 16.18$ & 0.982 \\
Hip (cm) & $105.76 \pm 13.86$ & $107.89 \pm 13.32$ & $104.47 \pm 14.04$ & 0.016 \\
WHR & $0.85 \pm 0.10$ & $0.83 \pm 0.08$ & $0.86 \pm 0.11$ & 0.009 \\
Blood glucose level (mg/dL) & $102.14 \pm 36.14$ & $96.20 \pm 30.60$ & $106.54 \pm 39.22$ & 0.001 \\
TC (mg/dL) & $158.69 \pm 68.14$ & $156.77 \pm 68.66$ & $160.25 \pm 67.80$ & 0.594 \\
TG (mg/dL) & $106.80 \pm 73.25$ & $97.21 \pm 80.06$ & $114.55 \pm 66.42$ & 0.014 \\
\hline
\end{tabular}

WHR: waist-to-hip ratio, TC: Total cholesterol, TG: triglycerides.

Table 3. Prevalence of metabolic abnormalities and MetS among pre- and post-menopausal women.

\begin{tabular}{|c|c|c|c|c|}
\hline Metabolic abnormalities & $\begin{array}{l}\text { Overall } \\
\mathrm{n}(\%)\end{array}$ & $\begin{array}{l}\text { Pre-menopausal } \\
\text { women } \mathrm{n}(\%)\end{array}$ & $\begin{array}{l}\text { Post-menopausal } \\
\text { women } \mathrm{n}(\%)\end{array}$ & P-value ${ }^{a}$ \\
\hline Overweight $\left(\mathrm{BMI} \geq 25 \mathrm{~kg} / \mathrm{m}^{2}\right)$ & $318(63.9)$ & $138(65.1)$ & $180(62.9)$ & 0.620 \\
\hline Overweight (BMI: 25 - 29.9 kg/m²) & $146(29.4)$ & $60(28.3)$ & $86(30.0)$ & 0.981 \\
\hline Obesity (BMI $\left.\geq 30 \mathrm{~kg} / \mathrm{m}^{2}\right)$ & $172(34.6)$ & $78(36.8)$ & $94(22.8)$ & 0.416 \\
\hline High waist circumference $(\mathrm{WC} \geq 80 \mathrm{~cm})$ & $259(56.6)$ & $106(56.4)$ & $153(56.7)$ & 0.952 \\
\hline High waist-to-hip ratio (WHR $\geq 0.80$ ) & $240(48.1)$ & $77(36.3)$ & $163(56.8)$ & $<0.001$ \\
\hline $\begin{array}{l}\text { Hyperglycemia (Blood glucose level } \geq \\
100 \mathrm{mg} / \mathrm{dL} \text { ) }\end{array}$ & $168(33.7)$ & $57(26.9)$ & $111(38.7)$ & 0.006 \\
\hline Prediabetes $(110-125 \mathrm{mg} / \mathrm{dL})$ & $75(15)$ & $33(15.6)$ & $42(14.6)$ & 0.857 \\
\hline Diabetes (glycemia $\geq 126 \mathrm{mg} / \mathrm{dL}$ ) & $54(10.8)$ & $12(5.7)$ & $42(14.6)$ & 0.001 \\
\hline $\begin{array}{l}\text { Hyperlipidemia (hyper TC and or } \\
\text { hyper TG) }\end{array}$ & $170(38.6)$ & $61(30.8)$ & $109(45.0)$ & 0.002 \\
\hline $\begin{array}{l}\text { Hypercholesterolemia (TC } \geq 200 \\
\mathrm{mg} / \mathrm{dL} \text { ) }\end{array}$ & $81(18.4)$ & $32(16.2)$ & $49(20.2)$ & 0.271 \\
\hline $\begin{array}{l}\text { Hypertriglyceridemia ( } \mathrm{TG} \geq 150 \\
\mathrm{mg} / \mathrm{dL} \text { ) }\end{array}$ & $104(24.1)$ & $33(17.1)$ & $71(29.7)$ & 0.002 \\
\hline $\begin{array}{l}\text { Elevated blood pressure }(\mathrm{SBP} \geq 130 \\
\mathrm{mmHg} \text { and/or } \mathrm{DBP} \geq 85 \mathrm{mmHg})\end{array}$ & $314(62.9)$ & $119(56.1)$ & $195(67.9)$ & 0.007 \\
\hline $\begin{array}{l}\text { Hypertension }(\mathrm{SBP} \geq 140 \mathrm{mmHg} \\
\text { and/or } \mathrm{DBP} \geq 90 \mathrm{mmHg})\end{array}$ & $230(46.1)$ & $89(42.0)$ & $141(49.1)$ & 0.113 \\
\hline MetS & $150(30.1)$ & $53(25.0)$ & $97(33.8)$ & 0.034 \\
\hline
\end{tabular}

Results were expressed as percentage (\%) and number of participants (n). a = p-value obtained by chisquare test 
triglycerides level (29.7\%), elevated blood pressure (67.9\%) and HTN (49.1\%) compared to pre-menopausal women $(\mathrm{P}<0.05)$. The most frequent metabolic abnormality among post-menopausal women was elevated blood pressure meanwhile overweight (BMI $\geq 25 \mathrm{~kg} / \mathrm{m}^{2}$ ) was the most frequent metabolic abnormality among pre-menopausal women. The prevalence of MetS was 30.1\% in the overall study population and post-menopausal women remained more affected with $33.8 \%$ versus $25 \%$ for pre-menopausal women $(\mathrm{p}=0.034)$ (Table 3 ).

\subsection{Risk of Developing Metabolic Abnormalities and Metabolic Syndrome with or without Age Adjustment}

Table 4 shows odds ratio (OR) and 95\% confidence interval (CI) of metabolic abnormalities and MetS among post versus pre-menopausal women in two models: the first without age as covariate and the second with age as covariate. Under age control, post-menopausal women were more likely to be overweight $\left(\mathrm{BMI} \geq 25 \mathrm{~kg} / \mathrm{m}^{2}\right)(\mathrm{OR}=1.90095 \% \mathrm{CI}: 1.034-3.489)$ and have high waist circumference (2.1 times) but this was attenuated and became non-significant without age control. The observation was not the same for high TG level and MetS where risk were 2.3 and 1.8 times respectively with age control and were slightly reduced but remained significant without age control $(\mathrm{OR}=2.049$ and

Table 4. Odd ratio of metabolic abnormalities and MetS among post-menopausal unadjusted and adjusted to age.

\begin{tabular}{|c|c|c|c|c|c|}
\hline Metabolic abnormalities & $\begin{array}{l}\text { Pre- } \\
\text { menopausal }\end{array}$ & $\begin{array}{l}\text { Post-menopausal OR }(95 \% \\
\text { CI) Without age control }\end{array}$ & P-value & $\begin{array}{l}\text { Post-menopausal OR }(95 \% \\
\text { CI) with age control }\end{array}$ & P-value \\
\hline Overweight (BMI $\geq 25 \mathrm{~kg} / \mathrm{m}^{2}$ ) & 1 & $0.911(0.629-1.319)$ & 0.620 & $1.900(1.034-3.489)$ & 0.039 \\
\hline Overweight (BMI: 25 - 29.9 kg/m²) & 1 & $1.013(0.650-1.580)$ & 0.981 & $1.844(0.850-4.000)$ & 0.121 \\
\hline Obesity (BMI $\geq 30 \mathrm{~kg} / \mathrm{m}^{2}$ ) & 1 & $1.205(0.789-1.839)$ & 0.416 & $1.989(0.991-3.994)$ & 0.053 \\
\hline High waist circumference $(\mathrm{WC} \geq 80 \mathrm{~cm}$ ) & 1 & $1.012(0.695-1.473)$ & 0.952 & $2.117(1.150-3.896)$ & 0.016 \\
\hline High waist-to-hip ratio (WHR $\geq 0.80$ ) & 1 & $2.201(1.436-3.375)$ & $<0.001$ & $1.396(0.723-2.694)$ & 0.320 \\
\hline $\begin{array}{l}\text { Elevated fasting blood glucose (glycemia } \geq 100 \\
\mathrm{mg} / \mathrm{dL} \text { ) }\end{array}$ & 1 & $1.715(1.166-2.522)$ & 0.006 & $1.226(0.991-1.056)$ & 0.510 \\
\hline Prediabetes (glycemia $110-125$ mg/dL) & 1 & $1.047(0.635-1.726)$ & 0.857 & $0.817(0.360-1.857)$ & 0.630 \\
\hline Diabetes (glycemia $\geq 126$ mg/dL) & 1 & $2.879(1.468-5.646)$ & 0.001 & $2.135(0.813-5.607)$ & 0.124 \\
\hline Hyperlipidemia (high TC and or high TG) & 1 & $1.841(1.241-2.729)$ & 0.002 & $1.174(0.937-3.320)$ & 0.079 \\
\hline High TC (TC $\geq 200 \mathrm{mg} / \mathrm{dL})$ & 1 & $1.317(0.806-2.153)$ & 0.271 & $0.889(0.410-1.972)$ & 0.742 \\
\hline High TG (TG $\geq 150$ mg/dL) & 1 & $2.049(1.285-3.266)$ & 0.002 & $2.384(1.160-4.903)$ & 0.018 \\
\hline $\begin{array}{l}\text { Elevated blood pressure (SBP } \geq 130 \mathrm{mmHg} \text { and } \\
\text { or DBP } \geq 85 \mathrm{mmHg} \text { ) }\end{array}$ & 1 & $1.656(1.147-2.392)$ & 0.007 & $1.233(0.680-2.235)$ & 0.490 \\
\hline $\begin{array}{l}\text { Hypertension ( } \mathrm{SBP} \geq 140 \mathrm{mmHg} \text { and or } \mathrm{DBP} \geq \\
90 \mathrm{mmHg} \text { ) }\end{array}$ & 1 & $1.335(0.933-1.909)$ & 0.113 & $1.065(0.610-1.888)$ & 0.829 \\
\hline Metabolic syndrome & 1 & $1.532(1.031-2.275)$ & 0.034 & $1.888(1.016-3.507)$ & 0.044 \\
\hline
\end{tabular}

BMI: Body Mass Index; TC: total cholesterol; TG: triglycerides; OR: odds ratio; CI: confidence interval; a: age was inserted as a continuous variable in a Multivariate logistic regression. The Odds ratio (OR) of developing metabolic abnormalities was evaluated among post-menopausal women comparatively to pre-menopausal women considered as reference group. 
1.53 respectively). After age-adjustment, the risk of high waist-to-hip ratio, hyperglycemia, diabetes and hyperlipidemia were attenuated and became nonsignificant (Table 4).

\section{Discussion}

CVD remains one of the main causes of mortality worldwide and MetS increases the risk of CVD as well as morbidity of the disease. Studies have shown that women are at a lesser risk of developing CVD than their male counterparts before menopause, but this advantage is abolished after menopause. Also, female coronary heart diseases (CHD) morbidity rates accelerate more quickly than do those of males after the age of 45 years [34]. The present study, which aims at evaluating and comparing the effect of menopausal status on the outcome of metabolic abnormalities and MetS suggested that Cameroonian menopausal women were more at risk of CVD than pre-menopausal women. According to Kim et al. study on Korean women, post-menopausal women had significantly higher WC, SBP, pulse pressure, total cholesterol, LDL cholesterol, and triglyceride levels than pre-menopausal [19]. These observations were similar to our results (except for WC) where means of SBP, DBP, WHR, glucose and triglycerides levels were significantly higher among post-menopausal than pre-menopausal women (Table 2). During menopause, the pattern of hormone secretion changes and gradually causes fat accumulation in visceral tissues of abdomen and as a result central obesity. Estrogen promotes the accumulation of gluteo-femoral fat and the loss of estrogen with menopause is associated with an increase in central fat [35]. Also, the loss of ovarian function results in adverse changes in lipoprotein profile, glucose and insulin metabolism, body fat distribution, coagulation, fibrinolysis and vascular endothelial dysfunction [36] [37].

The assessment of metabolic abnormalities revealed an increased prevalence of impaired glucose level (glycemia $\geq 100 \mathrm{mg} / \mathrm{dL}$ ) (38.7\%), diabetes (14.6\%), hyperlipidemia (45.0\%), high triglycerides level (29.7\%), elevated blood pressure (67.9\%) and HTN (49.1\%) among post-menopausal compared to pre-menopausal women $(\mathrm{P}<0.05)$ (Table 3$)$. Results in Table 4 also confirmed increasing risk of some metabolic abnormalities among these post-menopausal participants. These results were consistent with many other studies [19] [38] [39] [40]. Ben Ali et al. [18] found that, except for hypertriglyceridemia, the frequency of central obesity, hyperglycemia, high blood pressure, and high total cholesterol level was significantly higher among post-menopausal than pre-menopausal Tunisian women. Jesmin et al., [14] noted that prevalence of high blood pressure, elevated fasting blood glucose and high triglycerides level was significantly higher in post-menopausal women than pre-menopausal women $(\mathrm{P}<0.05)$ among rural women in Bangladesh. Lack of estrogen is the main cause of these metabolic alterations. Apart from maintaining friendly lipid profile, estrogen changes the vascular tone by increasing nitrous oxide production. It stabilizes the endothelial cells, enhances antioxidant effects and alters fibrinolytic protein [41] [42]. In ad- 
dition, estrogen engages several mechanisms that protect against HTN, such as activation of the vasodilator pathway mediated by nitric oxide and prostacyclin and inhibition of the vasoconstrictor pathway mediated by the sympathetic nervous system and angiotensin [43]. All these cardioprotective mechanisms are lost in menopause and post-menopausal women develop an increased risk for CVD as consequence [44].

As concerns the clustering of metabolic abnormalities known as MetS, the present study revealed that post-menopausal women (33.8\%) were significantly more affected than pre-menopausal women $(25 \%)(\mathrm{p}=0.034)$ (Table 3). This was also confirmed by results in Table 4. Post-menopausal women were 1.5 (95\% CI: 1.031 - 2.275) times at risk of MetS compared to pre-menopausal women (reference group) in an unadjusted model, but when adjusted to age, the risk increased and became 1.9 times (95\% CI: 1.016 - 3.507). The prevalence of MetS among post-menopausal women (33.8\%) was higher than $16.5 \%$ (NCEP ATP III definition) obtained by Mandob et al., [21] among a group of 206 postmenopausal women in Yaounde (Cameroon). The present results are in accordance with Ben Ali et al. study who found that Tunisian post-menopausal women $(45.7 \%)$ were more affected by MetS than premenopausal women (25.6\%) [18]. Jesmin et al. also noted that 39.3\% of post-menopausal women had MetS as compared to pre-menopausal (16.8\%) rural women in Bangladesh [14]. Additionally, the overall prevalence of MetS was $30.1 \%$ (Table 3). This prevalence was lower than $46.1 \%$ found by Marbou and Kuete [45] among Cameroonian women living in the West Region. The difference could be attributed to MetS definition used, in their study, they used standard IDF criteria while in our study, HDL was replaced by total cholesterol.

\section{Conclusion}

Our results show that post-menopausal status might be a predictor of metabolic abnormalities and metabolic syndrome. Thus, special attention needs to be paid to this group of population to reduce the outcome of cardiovascular events.

\section{Limitations}

Some limitations need to be mentioned. Firstly, an association derived from a cross-sectional study does not necessarily indicate causality. Secondly, menopausal status was self-reported and could have recall bias. Thirdly, total cholesterol was used instead of HDL-cholesterol assayed through the precipitation method which is known for its large variability.

\section{Authors' Contributions}

NFR designed the study plan and drafted the questionnaire; NFR, MAMA, AKBG, NWM, TTBR, MMO collected data and performed biochemical analysis; NFR analyzed the data and wrote the manuscript, NJL and OJE supervised the overall procedure. All authors read and approved the final manuscript. 


\section{Funding}

This work was not supported by a grant or funding.

\section{Conflicts of Interest}

The authors declare no conflicts of interest regarding the publication of this paper.

\section{References}

[1] Alberti, K.G.M.M., Eckel, R.H., Grundy, S.M., Zimmet, P.Z., Cleeman, J.I., Donato, K.A., et al. (2009) Harmonizing the Metabolic Syndrome, a Joint Interim Statement of the International Diabetes Federation Task Force on Epidemiology and Prevention; National Heart, Lung, and Blood Institute; American Heart Association; World Health Federation; and International Atherosclerosis Society; and International Association for the Study of Obesity. Circulation, 120, 1640-1645. https://doi.org/10.1161/CIRCULATIONAHA.109.192644

[2] Kaur, J. (2014) A Comprehensive Review on Metabolic Syndrome. Cardiology Research and Practice, 2014, Article ID: 943162. https://doi.org/10.1155/2014/943162

[3] Faijer-Westerink, H.-J., Kengne, A.P., Meeks, K.A.C. and Agyemang, C. (2020) Prevalence of Metabolic Syndrome in Sub-Saharan Africa: A Systematic Review and Meta-Analysis. Nutrition, Metabolism and Cardiovascular Diseases, 30, 547-565. https://doi.org/10.1016/j.numecd.2019.12.012

[4] Adeoye, A.M., Adewoye, I.A., Dairo, D.M., Adebiyi, A., Lackland, D.T., Ogedegbe, G. and Tayo, B.O. (2015) Excess Metabolic Syndrome Risks among Women Health Workers Compared with Men. The Journal of Clinical Hypertension (Greenwich), 17, 880-884. https://doi.org/10.1111/jch.12595

[5] Gradidge, P.J.L. and Crowther, N.J. (2017) Review: Metabolic Syndrome in Black South African Women. Ethnicity \& Disease, 27, 189-200. https://doi.org/10.18865/ed.27.2.189

[6] Carr, M.C. (2003) The Emergence of the Metabolic Syndrome with Menopause. The Journal of Clinical Endocrinology \& Metabolism, 88, 2404-2411. https://doi.org/10.1210/jc.2003-030242

[7] Mesch, V.R., Boero, L.E., Siseles, N.O., Royer, M., Prada, M., Sayegh, F., Schreier, L., Benencia, H.J. and Berg, G.A., (2006) Metabolic Syndrome throughout the Menopausal Transition: Influence of Age and Menopausal Status. Climacteric, 9, 40-48. https://doi.org/10.1080/13697130500487331

[8] Lejsková, M., Alušík, S., Suchánek, M., Zecová, S. and Pitha, J. (2011) Menopause: Clustering of Metabolic Syndrome Components and Population Changes in Insulin Resistance. Climacteric, 14, 83-91. https://doi.org/10.3109/13697131003692745

[9] Ko, S.H. and Kim, S.H. (2020) Menopause-Associated Lipid Metabolic Disorders and Foods Beneficial for Postmenopausal Women. Nutrients, 12, 202. https://doi.org/10.3390/nu12010202

[10] Rosenthal, T. and Oparil, S. (2000) Hypertension in Women. Journal of Human Hypertension, 14, 691-704. https://doi.org/10.1038/sj.jhh.1001095

[11] Gierach, G.L., Johnson, D., Bairey, M.N., Kelsey, S.F., Bittner, V., Olson, M.B., Shaw, L.J., Mankad, S., Pepine, C.J., Reis, S.E., Rogers, W.J., Sharaf, B.L. and Sopko, G., WISE Study Group (2006) Hypertension, Menopause, and Coronary Artery Disease Risk in the Women's Ischemia Syndrome Evaluation (WISE) Study. Journal of the American College of Cardiology, 47, S50-S58. 
https://doi.org/10.1016/j.jacc.2005.02.099

[12] Mendelsohn, M.E. and Karas, R.H. (1999) The Protective Effects of Estrogen on the Cardiovascular System. The New England Journal of Medicine, 340, 1801-1811. https://doi.org/10.1056/NEJM199906103402306

[13] Paschou, S.A. and Papanas, N. (2019) Type 2 Diabetes Mellitus and Menopausal Hormone Therapy: An Update. Diabetes Therapy, 10, 2313-2320. https://doi.org/10.1007/s13300-019-00695-y

[14] Jesmin, S., Islam, A.M.S., Sakter, I.M.M., Sultana, S.N., Yamaguchi, N., Okazaki, O., Moroi, M., Hiroe, M., Kimura, S., Watanabe, T., Saturo, K. and Mizutani, T. (2013) Metabolic Syndrome among Pre- and Post-Menopausal Rural Women in Bangladesh: Result from a Population-Based Study. BMC Research Notes, 6, Article No. 157. https://doi.org/10.1186/1756-0500-6-157

[15] Mesch, V.R., Siseles, N.O., Maidana, P.N., Boero, L.E., Sayegh, F., Prada, M., Royer, M., Schreier, L., Benencia, H.J. and Berg G.A. (2008) Androgens in Relationship to Cardiovascular Risk Factors in the Menopausal Transition. Climacteric, 11, 509-517. https://doi.org/10.1080/13697130802416640

[16] Janssen, I., Powell, L.H., Crawford, S., Lasley, B. and Sutton-Tyrrell, K. (2008) Menopause and The Metabolic Syndrome: The Study of Women's Health across the Nation. Archives of Internal Medicine, 168, 1568-1575. https://doi.org/10.1001/archinte.168.14.1568

[17] Rosano, G.M.C., Vitale, C., Marazzi, G. and Volterrani, M. (2007) Menopause and Cardiovascular Disease: The Evidence. Climacteric, 10, 19-24. https://doi.org/10.1080/13697130601114917

[18] Ben Ali, S., Belfki-Benali, H., Aounallah-Skhiri, H., Traissac, P., Maire, B., Delpeuch, F., Achou, R.N. and Ben Romdhane, H. (2014) Menopause and Metabolic Syndrome in Tunisian Women. BioMed Research International, 2014, Article ID: 457131. https://doi.org/10.1155/2014/457131

[19] Kim, H.M., Park, J., Ryu, S.Y. and Kim, J. (2007) The Effect of Menopause on the Metabolic Syndrome among Korean Women: The Korean National Health and $\mathrm{Nu}-$ trition Examination Survey, 2001. Diabetes Care, 30, 701-706. https://doi.org/10.2337/dc06-1400

[20] Eshtiaghi, R., Esteghamati, A. and Nakhjavani, M. (2010) Menopause Is an Independent Predictor of Metabolic Syndrome in Iranian Women. Maturitas, 65, 262-266. https://doi.org/10.1016/j.maturitas.2009.11.004

[21] Mandob, D.E., Rosalie, N.K. and Marlyse, L.K. (2015) Prevalence of Metabolic Syndrome among Postmenopausal Women Yaounde-Cameroon. International Journal of Health Sciences and Research, 5, 278-284. https://doi.org/10.4172/2167-0943.1000186

[22] Soules, M.R., Sherman, S., Parrott, E., Rebar, R., Santoro, N., Utian, W. and Woods, N. (2001) Executive Summary: Stages of Reproductive Aging Workshop (STRAW). Fertility and Sterility, 76, 874-888. https://doi.org/10.1016/S0015-0282(01)02909-0

[23] Trinder, P. (1969) Determination of Glucose in Blood Using Glucose Oxidase with an Alternative Oxygen Acceptor. Annals of Clinical Biochemistry, 6, 24-27. https://doi.org/10.1177/000456326900600108

[24] Richmond, W. (1973) Preparation and Properties of a Cholesterol Oxidase from Nocardia Sp. and Its Application to the Enzymatic Assay of Total Cholesterol in Serum. Clinical Chemistry, 19, 476-482. https://doi.org/10.1093/clinchem/19.12.1350

[25] Fossati, P. and Principe, L. (1982) Serum Triacylglycerols Determined Colorimetrical- 
ly with an Enzyme That Produces Hydrogen Peroxide. Clinical Chemistry, 28, 2077-2080. https://doi.org/10.1093/clinchem/28.10.2077

[26] World Health Organization (2003) Obesity, Prevention and Management of World Epidemy. Technical Reports Series, No. 916. World Health Organization, Geneva.

[27] Alberti, K.G., Zimmet, P. and Shaw, J. (2006) Metabolic Syndrome: A New World-Wide Definition. A Consensus Statement from the International Diabetes Federation. Diabetic Medicine, 23, 469-480. https://doi.org/10.1111/j.1464-5491.2006.01858.x

[28] The Expert Committee on the Diagnostic and Classification of Diabetes Mellitus (2003) Report of the Expert Committee on Diagnosis and Classification of Diabetes Mellitus. Diabetes Care, 26, S5-S20. https://doi.org/10.2337/diacare.26.2007.S5

[29] Expert Panel on Detection, Evaluation, and Treatment of High Blood Cholesterol in Adults (2001) Executive Summary of the Third Report of the National Cholesterol Education Program (NCEP) Expert Panel on Detection, Evaluation, and Treatment of High Blood Cholesterol in Adults (Adult Treatment Panel III). JAMA, 285, 2486-2497. https://doi.org/10.1001/jama.285.19.2486

[30] Guidelines Subcommittee (1999) 1999 World Health Organization-International Society of Hypertension Guidelines for the Management of Hypertension. Journal of Hypertension, 17, 151-183. https://doi.org/10.1097/00004872-199917020-00001

[31] Mandob, E.D., Ngondi, J.L., Fomekong, D.I.G., Agbor, G. and Oben, J.E. (2008) Prediction and Prevalence of Metabolic Syndrome in Overweight and Obese Subjects in Cameroon. International Journal of Biomedical and Pharmaceutical Sciences, 2, Global Science Books.

[32] Fezeu, L., Balkau, B., Kengne, A.-P., Sobngwi, E. and Mbanya, J.-C. (2007) Metabolic Syndrome in a Sub-Saharan African Setting: Central Obesity May Be the Key Determinant. Atherosclerosis, 193, 70-76. https://doi.org/10.1016/j.atherosclerosis.2006.08.037

[33] Belfki, H., Ben Ali, S., Aounallah-Skhiri, H., Traissac, P., Bougatef, S., Maire, B., Delpeuch, F., Achour, N. and Ben Romdhane, H. (2013) Prevalence and Determinants of the Metabolic Syndrome among Tunisian Adults: Results of the Transition and Health Impact in North Africa (TAHINA) Project. Public Health Nutrition, 16, 582-590. https://doi.org/10.1017/S1368980012003291

[34] Couderc, R. and Maachi M. (1999) Lipoprotein (A): Risk Factor for Atherosclerotic Vascular Disease Important to Take into Account in Practice. Annales de Biologie Clinique (Paris), 57, 157-167.

[35] Poehlman, E.T., Toth, M.J. and Gardner, A.W. (1995) Changes in Energy Balance and Body Composition at Menopause: A Controlled Longitudinal Study. Annals of Internal Medicine, 123, 673-675. https://doi.org/10.7326/0003-4819-123-9-199511010-00005

[36] Bales, A.C. (2000) In Search of Lipid Balance in Older Women; New Studies Raise Questions about What Works Best. Postgrad Medicine, 108, 57-72. https://doi.org/10.3810/pgm.2000.12.1312

[37] Eltayeb, H.A., Modawe, G.A. and Abdrabo, A.A. (2015) Assessment of Lipid Profile in Premenopausal and Postmenopausal Sudanese Women. Pyrex Journal of Biomedical Research, 1, 11-13.

[38] Gweh, J.C., Nwagha, I.U. and Okaro, J.M. (2005) The Effects of Menopause on the Serum Lipid Profile of Normal Females of South East Nigeria. Nigerian Journal of Physiological Sciences, 20, 48-53.

[39] Jouyandeh, Z., Nayebzadeh, F., Qorbani, M. and Asadi, M. (2013) Metabolic Syn- 
drome and Menopause. Journal of Diabetes \& Metabolic Disorders, 12, Article No. 1. https://doi.org/10.1186/2251-6581-12-1

[40] Sapkota, A.S., Sapkota, A., Acharya, K., Raut, M. and Jha, B. (2015) Study of Metabolic Syndrome in Postmenopausal Women. Annals of Clinical Chemistry and Laboratory Medicine, 1, 6-11. https://doi.org/10.3126/acclm.v1i1.12307

[41] Subbiah, M. (1998) Mechanisms of Cardioprotection by Estrogens. Proceedings of the Society for Experimental Biology, 217, 23-29. https://doi.org/10.3181/00379727-217-44201

[42] Iorga, A., Cunningham, M.C., Moazeni, S., Ruffenach, G., Umar, S. and Mansoureh, E. (2017) The Protective Role of Estrogen and Estrogen Receptors in Cardiovascular Disease and the Controversial Use of Estrogen Therapy. Biology of Sex Differences, 8, Article No. 33. https://doi.org/10.1186/s13293-017-0152-8

[43] Ashraf, M.S. and Vongpatanasin, W. (2006) Estrogen and Hypertension. Current Hypertension Reports, 8, 368-376. https://doi.org/10.1007/s11906-006-0080-1

[44] Srinivas, R.K. and Srinivasa, R.C. (2013) A Comparative Study of Lipid Profile and Oestradiol in Pre- and Post-Menopausal Women. Journal of Clinical and Diagnostic Research, 7, 1596-1598.

[45] Marbou, W.J.T. and Kuete, V. (2019) Prevalence of Metabolic Syndrome and Its Components in Bamboutos Division's Adults, West Region of Cameroon. BioMed Research International, 2019, Article ID: 9676984.

https://doi.org/10.1155/2019/9676984 